\title{
Controle de vassoura-de-bruxa
}

Rolf Singer

Instituto Nacional de Pesquisos

da Amaxónia, Manaus

As cascas do cacau, após a colheita são, na maioria das vezes, jogacias fora em um lugar perto da plantação, onde são amontoadas para formaçăo de composto (adubo orgânico). Esta técnica não oferece qualquer perigo em regiōes onde não existem espécies nativas de Theobroma e, portanto, não há ocorrência de Crinipellis perniciosa (fungo patogênico que causa a vassoura-de-bruxa ou krulloten). Entretanto, onde tais condições não existem, isto é onde se espera infecçōes por Crinipellis, verifiquei que tal técnica causa um dano incalculável, pois é um verdadeiro convite à infecção. Isso fará com que plantações experimentais percam seu valor e pode destruir as novas plantações.

Numa exploração micológica que fiz nos arredores de Manaus, verifiquei que na estação da EMBRAPA, do $\mathrm{Km} \mathrm{30}$, na estrada Manaus-
Itacoatiara, tais montículos de cascas são co. locados a menos de 50 metros das plantações. Nessa excursão que fiz constatei que existem carpóforos de $C$. perniciosa (cujos espécimes estão depositados no INPA. Manaus) em quantidade apreciável nesses montículos, de onde uma enorme quantidade de esporos pode ser livremente transportada para as plantações, levada por correntes de ar, nas vestimentas dos trabalhadores ou em seus instrumentos agrícolas.

Sugiro fortemente que as cascas sejam queimadas (que é o melhor, se o tempo for seco) ou enterradas, tendo pelo menos $20 \mathrm{~cm}$ de terra sobre a casca mais superficial, ou, se forem demorar a céu aberto por mais de uma semana, devem receber uma pulverizaçäo de fungicida. Todavia, um tal processo deveria ser repetido com freqüência e, portanto, poderá vir a ser economicamente proibitivo. 